\title{
PERSPEKTIEF OP DIE BANTOETUISLANDE
}

Die onderwerp wat ek moet bespreek, is: „Perspektief op die Bantoetuislande". Ek wil dit graag op so 'n wyse vertolk dat dit eintlik op 'n besinning oor breë beleid en die toepassing daarvan neerkom. Daarom gaan ek my probeer bepaal by hooftrekke van ons beleid van veelvolkige ontwikkeling en uitgebreide besonderhede vermy.

Hoewel Bantoetuislande ' $n$ sleutelbegrip is, is daar ander fasette in die beleidstoepassing wat gepaard gaan met Bantoetuislande en selfs voor die geografiese omlyning daarvan ons aandag verdien. Deur net die ekonomiese afhanklikheid van sommige van ons onafhanklike buurstate in oënskou te neem, kan besef word dat die skepping van ' $n$ aantal afgeslote tuislande sonder meer nie die finale antwoord is nie.

Ek besef maar al te goed dat die hedendaagse mens net met skouspelagtige gebeurtenisse tevrede gestel kan word. Indien hy dus nie langs hierdie weg bevredig word nie, skep hy in sy verbeelding sy eie „oplossings" wat hy dan op die werklikhede projekteer. Baie van hierdie skeppings is goed bedoel, dog sonder uitsondering dra hulle tot die totstandkoming van wanperspektiewe by, en sodra sake aldus buite hul verband getrek word, kry ons 'n verwarde beeld van die werklikheid.

Laat my dan ineens daarop wys dat ons beleid met 'n sosio-ekonomiese vraagstuk in die wydste $\sin$ van die woord te maak het en soos alle vraagstukke op hierdie terrein, moet ook die onderwerp onder bespreking binne sy maatskaplike raamwerk ontleed word. Ons kan dus nie eens die eensydige beklemtoning van die een of ander aspek van die geheel toelaat nie, omdat daar noulettend teen die ontstaan van verkeerde beelde gewaak moet word. In die tydsbestek waarin ons leef, is ons universiteite veral geroepe om op die terrein van die geesteswetenskappe meer as ooit tevore objektiewe en gebalanseerde beskouings te bevorder. Alleen langs hierdie weg kan 'n oortuigde openbare mening vir die toekoms opgebou word, want dit sal baie bydra om verwarring en dwaling in ons beleidstoepassing uit die weg te ruim. Daar moet nie uit die oog verloor word dat massamedia die beeld van die beleid wat Suid-Afrika volg, help skep nie. Indien diegene wat geroepe is om dus leiding aan die gemeenskap te gee, self nie die regte beeld van die beleid na buite uitdra nie, kan daar nie verwag 
word dat die breë volksmassa ooit die angeleenthede in hul regte perspektief sal kan sien nie.

Gebrekkige insig in en kennis van die vraagstukke wat in die weg van beleidstoepassing lê, neig by buitestaanders daartoe dat hulle met 'n eenvoudige resep voor die dag kom in die hoop dat die ,wondermiddel” naarstiglik aangegryp sal word.

In hierdie verband moet daar nie net rekening gehou word met die beterweters en wensdenkers wat 'n skouspelagtige beleidstoepassing verlang nie, maar ook met diegene wat bereid is om 'n Westerse leefwyse in Afrika op te offer deur dit aan 'n proses van integrasie uit te lewer.

Dit val dan ook dadelik op dat baie kritici die sukses of mislukking van die beleid aan absolute geografiese skeiding tussen die onderskeie tuislande in Suid-Afrika koppel. Volgens hierdie siening moet alle Bantoe-persone onmiddellik die blanke tuisland verlaat en na hul eie tuislande trek.

Indien hierin nie dadelik geslaag word nie, is die beleid volgens diesulkes tot mislukking gedoen. Persone wat hierdie norm sonder meer gebruik, is nie ten volle op hoogte van die wesentlike aspekte van die beleid van afsonderlike ontwikkeling nie. Hoe graag almal absolute gebiedskeiding op 'n tuislandgrondslag sou wil sien, en hoe graag ons sou wil sien dat daar in die blanke tuisland net van blanke arbeid gebruik gemaak word, mag ons nooit die werklikhede, waarby ek later kom, uit die oog verloor nie.

Terloops wil ek hier net melding maak van die wanvoorstellings wat daar van die aanwesigheid van Bantoe in die blanke gebied gemaak word. Eintlik is daar net drie miljoen manlike Bantoe-persone, volgens sensusgegewens in die blanke gebied werksaam. Van hierdie getal is daar minder as een derde afkomstig van die buurstate. Eintlik is daar dus net meer as twee miljoen manlike Bantoe-persone afkomstig van tuislande binne Suid-Afrika in die blanke gebied werksaam. 'n Groot aantal van hierdie werkers is boonop op 'n trekgrondslag in diens en is op dié wyse in gereelde verbinding met hul eie tuislande. 'n Uitbreiding van dorpstigting in Bantoetuislande, tesaam met vervoergeriewe, in die toekoms, kan dus nog groter getalle in hul tuislande veranker.

Die kern en wese van die beleid lê dus nie in die eerste instansie in die skouspelagtige verwydering van mense na hul onderskeie tuislande toe nie, maar in die proses van ontvoog- 
ding van die Bantoevolke en hul tradisionele, geestelike en politieke verankering aan hul tuislande. Om hierdie ontvoog. dingsproses te volvoer, moet daar altyd op die historiese agtergrond van die menslike verskynsels waarmee ons gemoeid is, ag geslaan word. In die lig van hierdie historiese ontwikkeling val dit dus dadelik op dat die uitvoering en deurvoering van die beleid nie net langs die weg van wetlike verordeninge of die uitvaardiging van dekrete kan geskied nie.

Op die breë front moet ons dus daarop ingestel wees om elke volk op die weg wat vreedsame naasbestaan sal moet bestendig, met ons saam te neem. Die suksesvolle aflegging van hierdie pad sal afhang van die egtheid, eerlikheid en opregtheid waarmee elke volk in Suid-Afrika vervul moet word.

In die lig van hierdie fundamentele uiteensetting wil ek dan 'n paar belangrike aspekte wat met die proses van ontvoogding gemoeid is, behandel. Dog ek wil 'n woord van waarskuwing uitspreek, naamlik dat wanperspektiewe nie net oor die globale beleid tot stand kom nie maar dat ook ten opsigte van elke afsonderlike onderdeel van die beleid sulke dwalings te bespeur is.

Eerstens wil ek dan die aandag op die volke vestig. Dit is maar baie onlangs dat die besef posgevat het dat daar in Afrika ' $n$ groot verskeidenheid volke is. Ook in Suid-Afrika kan die oë nie langer vir hierdie lewenswerklikheid gesluit word nie. Vantevore is daar slegs aan die indiwidue gedink sonder om te besef dat hierdie indiwidue ook volksverbonde is.

Deur so 'n verkeerde beeld oor die bewoners van Afrika te hê, word die basis van die beleid aangetas omdat primêr van die volksgrondslag uitgegaan moet word. Dit is absoluut fundamenteel.

Dit was as gevolg van die ontvoogdingsproses in Afrika dat die begrip „Bantoe” en „African” sy betekenis begin verloor het. In die plek daarvan het die volksnaam ingetree en die indiwidue word nou as lidmate van bepaalde volke en as burgers van bepaalde owerhede gesien. So kry ons dan 'n ryke verskeidenheid van volksname in Suider-Afrika soos Malawiërs, Botswanas en Basoetos om maar net 'n paar te noem.

Ook in Suid-Afrika het ons byvoorbeeld die Xhosavolk wat ongeveer uit drie miljoen mense bestaan, 'n Zoeloevolk van ongeveer dieselfde aantal, terwyl die Tswanavolk oor 'n sieletal van ongeveer een miljoen beskik. 
Die volvoering van die beleid impliseer dat elk van hierdie volke gehelp word in die proses van ontvoogding. Waar die verskillende volkslidmate hulle op die oomblik bevind, hetsy binne of buite hul onderskeie tuistes, is nie van deurslaggewende belang nie, hoewel dit wenslik is dat hulle hulle maksimaal in hul tuislande bevind. Baie van hulle is in die tuislande, terwyl ander weer werksaam is in die stedelike of landelike deel van die blanke tuisland. Dit maak ook nie saak waar die onderskeie onderdane gebore is nie; of dit nou op die plaas van ' $n$ boer is of dit in 'n stedelike Bantoewoonbuurt is, kom daar ook nie op aan nie. Die deurslaggewende faktor wat volkslidmaatskap bepaal, is nie die plek waar hulle gebore is nie, maar wel hul afkoms.

Deur vas te stel wie die ouers, grootouers en oorgrootouers van 'n bepaalde persoon is, kan ook die volkslidmaatskap bepaal word en kan elkeen dus by een van die bestaande volke ingedeel word. Die taal wat gebesig word, is ook 'n belangrike faktor om die volksindeling te kan maak.

Die voordele wat volkslidmaatskap meebring is talryk. Trouens, die indiwidu kan slegs in voorregte en regte deel indien hy lid van 'n volk is. Regte en voorregte is nie los te maak van volksgemeenskap nie en laasgenoemde kan bepaal hoe sy lidmate daardeur bevoordeel kan word. So byvoorbeeld, het die lidmate van die volk, waar hulle ook hulself toevallig mag bevind, ' $n$ deel in die grondbesit van die volksgemeenskap. Hulle het ' $n$ deel in die politieke ontwikkeling in die volkstuistes en hulle kan ook ten volle bevoordeel word deur die ekonomiese ontwikkeling in daardie volkstuistes. Lidmaatskap van 'n bepaalde volk is ' $n$ sosiologiese feit en daaraan moet formele of wetlike erkenning verleen word. 'n Voorwaartse stap in hierdie verband is reeds onder oorweging en hopelik sal daar op 'n vroeë stadium wetgewing ingedien word om die onderskeie owerhede in staat te stel om dokumente van burgerskap aan hul onderskeie onderdane uit te reik. So 'n identiteitsdokument kan as die voorloper van 'n eie paspoort beskou word. In daardie dokument sal deur die owerheid gesertifiseer word dat die houer of draer van die dokument 'n volwaardige lidmaat is van 'n bepaalde volksgemeenskap.

Die aanvaarding van volkslidmaatskap van ' $n$ volk is ' $n$ outomatiese handeling, want elke mens word binne 'n volksverband gebore en hy is trou verskuldig aan daardie volk. Wetge- 
wing hieroor sal dus net ' $n$ bevestiging van ' $n$ bestaande toestand wees, en tot tyd en wyl die verskillende owerhede in staat is om so 'n eie identiteitstelsel op te bou, sal hierdie dokumente van departementsweë namens die volksowerhede uitgereik word.

Ek dink dit is ons almal, blank sowel as nie-blank, se taak om tussen die afsonderlike volke wat ons in Suid-Afrika het behoorlik te differensieer en hulle behoorlik van mekaar te onderskei. Wat betref die Bantoevolke, die taak waarvoor ek aangestel is, ag ek dit my spesifieke plig en werk om alles wat moontlik is te doen om die verskillende afsonderlike Bantoevolke te help fondeer, te help vestig, te help vorm en te help uitbou as afsonderlike volke, sodat hulle die geestelike en die nasionale toevlugte kan wees vir elke lid van daardie verskillende Bantoevolke wat daar in Suid-Afrika is. Dit moet baie duidelik verstaan word dat ons in Suid-Afrika te doen het met 'n aantal Bantoevolke, 'n hele aantal van hulle, en as ons Suidwes-Afrika bytel nog meer Bantoevolke.

Wanneer elke persoon wetlik en wesenlik met sy eie volk en owerheid geïdentifiseer is, speel die kwessie van die arbeidsveld nie meer so ' $n$ pertinente rol nie, omdat die hele aangeleentheid van die arbeid, soos later aangetoon sal word, 'n aangeleentheid is wat Suider-Afrika vir homself na die beste van sy vermoë sal moet oplos.

Nou kom ek by 'n tweede aspek waaroor daar ook dikwels baie ligtelik gepraat word, en dit het op die konsolidasie van Bantoetuislande betrekking. Die pleitbesorgers vir die spoedige konsolidasie van die Bantoetuislande voer gewoonlik aan dat die administrasie van gebiede wat verspreid lê baie moeilik is. Ook word daarop gewys dat konsolidasie van verwante volke daardeur vertraag word. Wat egter uit die oog verloor word, is dat die grense van Afrika nie deur die verskillende Bantoevolke getrek is nie, maar wel deur die blanke owerhede wat in Afrika tot onlangs toe nog die gebiede geadministreer het. In hierdie verband moet daarop gewys word dat die grense geensins rekening met die bestaan van stamme en verwante stamme hou nie, met die gevolg dat daar oral in Afrika grense is wat stamme in twee deel, verwante stamme van mekaar skei en selfs nie-verwante en vyandige stamme weer binne dieselfde grense saamgroepeer. Die gevolg hiervan is dat dieselfde volksmense staatkundig by verskillende owerhede ingedeel is of dat vyandige stamme onder dieselfde owerheid ressorteer. 
Die bekendste voorbeelde vir ons almal is miskien die drie gewese protektorate wat al drie willekeurige grense gekry het met baie van hul mense daarbuite.

Wanneer ons die posisie in Suid-Afrika ontleed, vind ons dat die vraagstuk eweneens implikasies het en geensins eenvoudig is nie. Dit mag baie maklik wees om grense op 'n kaart aan te bring, maar dit is ' $n$ heel ander saak om bevolkings volgens ' $n$ voorafbeplande kaartstelsel in te deel. Vervolgens moet daarop gewys word dat in die afwesigheid van selfbesturende volksowerhede daar kwalik doeltreffende onderhandelings oor grensaangeleenthede en konsolidering van gebiede kan wees.

Daar is ook ander praktiese probleme soos die verspreide eiendomme van Bantoe-persone in blanke gebied, wat swart kolle genoem word. Dit is byvoorbeeld ook nie altyd so maklik om vergoedende grond van blankes te verkry ter opruiming van sulke swart kolle nie. Wanneer grond, gerieflik aan Bantoegebiede geleë, wel beskikbaar is, mag dit nie uit die oog verloor word dat dié grond vir Bantoe van 'n bepaalde volk of stam aangewend moet word nie, want dit deug nie om swartkolmense na ' $n$ verkeerde gebied te verskuif nie, want wanneer hulle van die swartkol verwyder word, moet hulle aansluiting by hul eie volk vind.

Dan is daar natuurlik nog die oorweging van die blankes wat nie 'n geringe rol in hierdie verband speel nie. Vergoedende grond moet meestal van blanke eienaars bekom word, en in hierdie proses is daar vir indiwiduele grondeienaars soms in 'n sekere mate ontwrigting of opoffering, sodat dit nie uitgesluit is nie dat daar in omtrent elke geval 'n langdurige proses van onderhandeling plaasvind voordat die finale stadium bereik is. Maar ook waar daar verskillende groepe of stamme van meer as een volk in dieselfde Bantoegebied woonagtig is, is daar probleme om hulle weer in te deel by hulle eie volke. Vervolgens moet ook onthou word dat alle Bantoetuislande nie ewe veel natuurlike hulpbronne besit nie, met die gevolg dat rekening met die menslike dravermoë van die besondere tuislande gehou moet word indien daar gedink word aan 'n grootskaalse konsolidasie van die bevolking in ' $n$ bepaalde Bantoetuisland.

Daar word dikwels verwys na die verwantskap van Bantoevolke wat aan beide kante van die Suid-Afrikaanse grense woon. 
Hoewel dit miskien nie uitgesluit is dat by wyse van 'n natuurlike groeiproses daar aansluitings in die toekoms kan plaasvind nie, is dit onprakties om daaraan te dink dat die horlosie in dié verband aangestoot kan word. Eweneens is dit net so onrealisties om stamme en bevolkingsgroepe saam te voeg wat nie histories bymekaar hoort nie. Die bloedige geskiedenis van sowel die Kongo as Nigerië is immers bewyse van die prys wat betaal word wanneer botsende groepe saamgedwing word.

Derdens wil ek graag die owerheidsektor behandel. Ook in hierdie verband word daar, soms uit onkunde maar soms ook uit vooroordeel, menings gehuldig wat nie met die historiese ontwikkeling in Afrika rekening hou nie. Almal weet dat die mees tradisionele gesag in Afrika dié van die stamhoof en raadsmanne is. Hoewel erken word dat dit moeilik is om 'n doeltreffende stelsel te hê indien daar met so baie kleiner owerhede onderhandel moet word, moet enige regeringstelsel tog hiermee rekening hou om bestendigheid te verseker.

Die kort geskiedenis van onafhanklike state in Afrika het getoon dat ' $n$ regeringsvorm wat uitsluitlik op die grondslag van 'n kiesstelsel tot stand kom, baie wankelend is vanweë die feit dat die Bantoe ' $n$ besondere eie demokratiese gesagstelsel het, gegrond op tradisionele stamme en die diepgewortelde tradisionele gesag van elke besondere Bantoevolk kan nie totaal oor die hoof gesien word nie. Hoewel hierdie tradisionele gesag. stelsel sy gebreke het, mag dit nie eenvoudig uit die weg gestoot word nie, omdat dit in der waarheid die groeibodem is vir 'n owerheidstelsel met moderne aanpassinge wat vir die Bantoevolke aanneemlik is. Ons is veral nou in Suid-Afrika besig met baie interessante hoewel veeleisende werk met die uitbouing van sulke volksowerhede vir elke Bantoevolk.

In Suid-Afrika word met hierdie feit rekening gehou en verskeie stukke wetgewing in die vorm van die Wet op Bantoeowerhede en die Wet op die Bevordering van Bantoe-selfbestuur, is reeds aanvaar terwyl wetgewing vir die Suidwes-volke binnekort behoort te volg. In al hierdie wette word nie net beslag aan hierdie tradisionele gesag gegee nie, maar is daar ook voorsiening vir modernisering om by die veelvuldige vereistes van 'n moderne samelewing aan te pas. Deur hierdie wetgewing is dit moontlik gemaak om die groot aantal stamregerings wat daar in die geledere van elke volk is, saam te snoer in 'n oorhoofse regeringstelsel wat as die gebiedsowerheid bekend staan. 
Die uitgeweke lede van 'n volk, meestal werksaam in blanke gebied, moet ook in die volk se owerheidstelsel betrek word. Hiervoor is daar in die geval van die Transkei reeds nuttige gebruik van die kiesstelsel gemaak, 'n patroon wat ook by die ander volke, hoewel waarskynlik in gewysigde vorm, toegepas kan word.

Dit is egter bekend dat die owerheid- of gesagsektor nie net oor wetgewende magte beskik nie maar ook 'n uitvoerende mag moet hê ten einde die landsadministrasie na behore te kan verrig.

In die ontvoogdingsproses is as eerste stap selfbestuur aan die Transkei toegeken deur die daarstelling van sowel 'n wetgewende as 'n uitvoerende gesag. Die fase wat ons nou binnetree is om daardie gebiedsowerhede wat nie oor 'n eie administrasie beskik nie, nou in staat te stel om nie net deel te hê in die formulering van beleid nie maar ook om hul eie wetgewing en die administrasie van hulle huishoudelike sake in die toekoms te behartig.

Ons is besig om vir elkeen van die oorblywende volke 'n eie hoofsetel te ontwikkel waar die wetgewende en die uitvoerende gesag gehuisves sal kan word. Elkeen van hierdie owerhede sal tot hul beskikking 'n aantal departemente hê wat aanvanklik in die boonste range met blanke amptenare beman sal wees. Amptenare sal aan die verskeie gebiedsowerhede beskikbaar gestel word en hulle sal dan daadwerklik betrek word by die opleiding van amptenare, maar hulle sal ook leiding gee aan die verskillende owerhede wat belas sal wees met die behartiging van hul eie departementele funksies.

Met hierdie stap wat ek noem die aktivering van die owerhede betree ons ' $n$ heel nuwe fase in ons administrasie. Tot dusver was die administrasie van ons Bantoetuislande sterk blank georiënteer. Voortaan sal hierdie administrasie meer Bantoe-sentries wees. Sodoende word daar nou 'n hegter grondslag gelê waarop alle Bantoevolke kan ontwikkel en waarvandaan hulle in die toekoms tot volledige selfbestuur en selfs tot onafhanklikheid as hulle daartoe in staat is, sal kan ontwikkel. Maar in hierdie verband wil ek dan graag 'n beroep op ons universiteite doen om ook hul kursusse by hierdie fase in beleidstoepassing aan te pas. Dusver is die administrateur van Bantoeaangeleenthede deur die wetgewing van die blanke parlement gelei, omdat in sy loopbaan hy hierdie wetgewing toegepas 
het. So het ons dan oor die jare heen 'n stelsel ontwikkel waarvolgens onder meer Bantoesakekommissarisse sowel as administrateurs van stedelike gebiede die verskillende lidmate van Bantoevolke binne en buite die Bantoetuislande administreer het.

Die administrasie wat van die student van die toekoms verlang gaan word, is om hom in die Bantoevolke se tuislande op 'n geleende grondslag te gaan vestig om daar met die ontwikkeling van 'n Staatsdiens van die Bantoevolk behulpsaam te wees en om ook die nodige leiding aan die betrokke lede van die owerhede te gee. Daar sal die Bantoevolkowerheid dan hulle eie wette maak en maatreëls tref waardeur aldaar eie soortgetroue volkswetgewing en -administrasie sal ontwikkel. Dit is egter nie voldoende dat ons net voldoende administrateurs sal oplei nie. Ons het nie net mense nodig wat in staatsadministrasie gekwalifiseer sal wees nie. Ten spyte van die tekort aan mannekrag wat die blanke gemeenskap van tyd tot tyd ondervind, sal dit van die blanke gemeenskap vereis word om ook tegniese en ander geskoolde kragte aan die verskillende owerhede te leen om hulle in staat te stel om nie net administratief bekwaam te raak nie, maar om ook op tegniese gebied hul eie ontwikkeling te behartig. Sodoende sal hul eie amptenare in staat gestel word om naas die akademiese opleiding ook prak. tiese ondervinding en indiensopleiding onder die toesig van bekwame en opgeleide blanke werkkragte te verrig.

Ek wil egter beklemtoon dat alle amptenare wat hulle in die toekoms wil toerus om hierdie groot taak te verrig, nie net geskoold moet wees in hul vak nie, maar hulle moet boweal sendingbewus wees, want van hulle sal groot opofferings geeis word. Hulle sal inderdaad pioniers in 'n nuwe werksveld wees.

Die ervaring in Afrika is dat daar selfbestuur en onafhanklikheid gekom het sonder dat die besondere owerhede oor die nodige opgeleide amptenary, tegnici en professionele kragte beskik het. Ons is daarvan bewus dat al die onafhanklike state opgeleide mense broodnodig het en dat tensy hierdie mense van elders aan hulle afgestaan word, ontwikkeling geweldig vertraag word.

Die blanke van Suid-Afrika wat tog deel van Afrika is, kan sy oë nie vir hierdie groot behoefte sowel binne as buite Suid-Afrika sluit nie, omdat sy eie bestaan en voortbestaan 
hierby gemoeid is. Ons sal in ons plig faal indien 'n helpende hand nie uitgesteek word nie. Of hulle sal sonder opgeleide personeel moet klaarkom of hulle sal van elders ingevoer word indien Suid-Afrika nie help nie.

Vervolgens wil ek my tot die arbeidsaangeleenthede van blanke werkgewers wend. Wanneer ons oor die onderwerp Bantoe-arbeid praat, val dit op dat daar heelwat verkeerde opvattings in hierdie verband bestaan. Die absolutiste of perfeksioniste eis dat die blanke dadelik van alle vorme van Bantoearbeid moet afsien. Die implikasies van so 'n standpunt word gerieflikheidshalwe nooit deur diesulkes grondig ondersoek nie. Afgesien daarvan dat so iets onrealisties is, word daar nooit rekenskap gegee van die lot wat miljoene werkers en hul af hanklikes sowel binne as buite Suid-Afrika sal tref, indien so iets moontlik sou wees nie.

Laat my toe om Bantoe-arbeid binne sy histories-ekonomiese verband aan $u$ te skets.

Dit is bekend dat die Bantoe nie oor 'n eie arbeidsgeskiedenis beskik nie. Werk het vir die Bantoe tradisioneel 'n heel ander betekenis as wat dit vir die blanke het, wat alreeds ' $n$ arbeidsgeskiedenis van 2,000 jaar of meer agter die rug het. Terwyl die blanke die arbeid beskou as ' $n$ middel om sy sluimerende talente te ontwikkel, om vir hom 'n loopbaan te verseker, om vir hom 'n status in die samelewing uit te werk en om groot etiese beginsels deur sy arbeid na te kom, daar vind ons dat die Bantoe sy arbeidsgeskiedenis alhier eers met die koms van die blanke begin het.

Waar arbeid by hom wel 'n deurlopende karakter begin kry het, was dit onder die invloed van die blanke se stelsel. So byvoorbeeld moes daar in toenemende mate loonarbeid verrig word om aan huishoudelike en belastingsvereistes te voldoen.

Dusver was sowel binne as buite Suid-Afrika die werkgeleentheid onvoldoende om die arbeidspotensiaal in die onderskeie Bantoetuistes te ontgin. Ook het die motivering tot die arbeid hoofsaaklik ontbreek, met die gevolg dat 'n arbeidsbewustheid nie kon ontwikkel het nie. Indien daarop gelet word dat die aanwending van menslike arbeid 'n voorvereiste vir menslike en gemeenskapsontwikkeling is, sou ' $n$ terugval tot of 'n aanmoediging van 'n loutere bestaansekonomie in Afrika 'n stap agteruit wees. Juis die teendeel moet plaasvind, naamlik 
'n opwekking van behoeftes aan verbruiksgoedere deur middel van die aanbring van geriewe binne die Bantoetuislande en deur die nabootsing van sodanige geriewe in die blanke gemeenskap.

Deur middel van verskeie metodes soos voorligting, opvoeding en voorbeelde moet alles in werking gestel word om 'n groter arbeidsbewustheid by die Bantoe te laat posvat, terwyl hy terselfdertyd tot die diens van sy eie volksgemeenskap moet toetree om daar, nie net in sy eie lewensbehoeftes te voorsien nie, maar ook om 'n diens aan sy volksgenote te lewer.

Niemand sal ontken dat die arbeidsprosesse die grootste beskawende faktor in menslike ontwikkeling is nie. Deur middel van die arbeid word nie net die moontlikhede in die mens blootgelê nie, ontwikkel hy nie net die talente en sy gawes nie, maar kan hy ook voorsien in daardie lewensbehoeftes wat met verloop van tyd vermeerder.

Dit het dan ook praktiese beleid geword om die mobilisering van die arbeid wat die registrasie en die indiensplasing van werksoekers insluit na die besondere stamowerhede te desentraliseer. Ons sal nog in hierdie jaar die nodige wetsvoorsienings by wyse van regulasie ankondig om hierdie owerhede in staat te stel om hul eie mense in werk te plaas. Hierdie indiensplasing sal vir sowel vakatures in die Bantoetuislande as dié in die blanke gebied geld.

Die blanke werkgewer sal voortaan meer en meer ag op die arbeidspatroon moet slaan.

Die arbeidspatroon wat tot dusver gegeld het, het al hoe meer gesinsarbeid in die blanke gebied meegebring. Hierdie arbeidspatroon sal moet verander deur arbeidsoorwigtige ondernemings in grensgebiede op te rig en waar moontlik daarheen te verskuif, deur arbeidstoestande so te reël dat werkers minstens naweke by hul gesinne in hul tuislanddorpe kan aansluit en deur met die vervoer van werkers na sulke tuistes behulpsaam te wees.

Vervolgens moet blanke werkgewers arbeidsbesparende metodes invoer. Hier word nie net aan meganisasie gedink nie maar ook bied die koöperatiewe benutting van arbeid groot moontlikhede in verband met arbeidsbesparing. Wanneer werkgewers in ' $n$ bepaalde bedryf hulle as ' $n$ werkgewersgroep registreer, sal dit nie net help dat knelpunte uitgeskakel kan 
word nie maar dit sal ook meehelp om die grootskaalse arbeidsomset te verminder.

'n Ander terrein waar daar heelwat mistasting voorkom, is in verband met die ekonomiese ontwikkeling van die Bantoetuislande. Hoewel toegegee word dat alle hulpbronne in die tuislande tot 'n maksimum moet ontwikkel sodat die menslike dravermoë aldaar tot die optimum opgestoot kan word, moet daar ook baie realisties in hierdie verband gedink word.

Die ekonome vertel ons dat daar vier basiese elemente by die ekonomiese prosesse betrokke is, naamlik ondernemerskap, kapitaal, die bodem en arbeid. Terwyl daar volop arbeid in die tuislande is, moet daar besef word dat hierdie arbeid in die eerste instansie nie opgelei is nie en in die tweede instansie die regte oriëntasie by die werkers nog nie bestaan nie. Ontwikkeling kan nooit op 'n persoon wat daarvoor nie vatbaar is nie, afgedwing word nie. Die vatbaarheid van die mens vir enige vorm van ontwikkeling is van deurslaggewende belang.

Ons weet dat die Bantoe tradisioneel bekend is met ' $n$ elementêre vorm van landbou en veeboerdery. Dit het egter meer die vorm van 'n bestaansekonomie as 'n bemarkingsekonomie. Om dus te verwag dat moderne boerderymetodes en nywerheidsontwikkeling maklik sal posvat, is wensdenkery. Grensnywerhede is 'n eerste stap om ontwikkeling in die tuislande te prikkel, want dit het die voordeel dat die werkers verbonde aan daardie nywerhede in hul eie tuistes gehuisves word.

Die totstandkoming van die Bantoebeleggingskorporasie en die Xhosa-ontwikkelingskorporasie was verdere stappe om hierdie ekonomiese ontwikkeling in die Bantoetuislande te bevorder.

Kragtens wetgewing wat vanjaar ingedien is om die bestaande wetgewing te verbeter, sal daar ook ander tipes korporasies tot stand kan kom. Deur hierdie liggame word daar kapitaal voorsien aan voornemende Bantoe-ondernemers, en daar word ook gepoog om sulke persone vaardigheid in hul bepaalde beroepe en besigheid in die algemeen aan te leer.

'n Saak waaroor daar soms baie vrae gestel word en misverstand heers, is hoe blanke ondernemerskap en kapitaal in die Bantoetuislande met ekonomiese ontwikkeling aldaar behulpsaam kan wees. Hieroor is reeds baie verduidelikings gegee. Ek herhaal wat ek en albei my voorgangers al gesê het: Die blanke kan nie as vrye ondernemer of as vennoot van Bantoe, in watter vorm ook al, in die Bantoegebiede toegelaat word nie. 
Dit moet onthou word dat die grondbeginsel van ons huidige verhouding tot die Bantoe in alle sake trusteeskap is, dit wil sê dat die blankes, onder aanvoering van hul Regering, die Bantoe as trustee of voog moet bystaan met alle ontwikkeling. Dit is nie 'n verhouding van werklike of teoretiese gelykheid soos in talle ander nie-blanke lande waar blank en nieblank vorme van vennootskap of gesamentlike ondernemings aanpak nie. Ons durf dus nie tydens ons trusteeskap ons eie mense (blankes) vryelik toelaat om hulle in die Bantoegebiede te vestig op so ' $n$ manier dat dit eintlik 'n verloëning van die trusteeskap is nie, want dit kan die Bantoe later tot vergelding laat oorgaan. Die manier waarop ons die Bantoevolke in en met hul tuislande help, is ons belangrikste "belegging" in die toekoms om goeie buurskap te kweek. Waar dit om goeie redes nie wenslik is dat Bantoe of ' $n$ korporasie self ' $n$ onderneming in 'n tuisland aanpak nie, soos ' $n$ myn byvoorbeeld, mag blankes, kragtens ooreenkoms as ' $n$ agent of kontrakteur dit vir eie rekening aandurf, maar op neergelegde voorwaardes, wat onder meer insluit ' $n$ billike vergoeding aan die Bantoesektor.

Een van die geldende beginsels wat van deurslaggewende belang is, is dat so ' $n$ ondernemer geen permanente regte en belange in vaste eiendom in die Bantoetuisland sal kan bekom nie.

Gepaard met hierdie ontwikkelingsaspekte, en eintlik primêr in belangrikheid, is natuurlik die ontwikkeling van die landboupotensiaal van die tuislande, en met die beskikbare fondse word gepoog om die landboupotensiaal uit te bou en om soveel moontlik indiwiduele gesinne op 'n landbougrondslag te plaas, terwyl die nodige opleiding aan toekomstige landbouers gegee word.

Ek wil dit baie duidelik stel dat die skepping van werkgeleentheid in die tuislande, ondanks die uiterste noodsaaklikheid daarvan, nie uit verband geruk moet word nie. So byvoorbeeld, sou die inpomp van kapitaal deur die owerheid nie enige vrugte afwerp nie, tensy dit prikkelend en stimulerend vir die plaaslike gemeenskappe is en die Bantoe ook skeppende bedrywighede en absorbering van die ontwikkelinge aan die dag lê. Ekonomiese ontwikkeling moet sy ontstaan en groei binne die gemeenskap hê en kan nie buite 'n gemeenskap deur buitestaanders bedryf word of op hulle afgedwing word nie.

Dit is om dieselfde rede dat ons elke poging in die werk 
stel om maatskaplike inrigtings en dienste, soos universiteite en ander opvoedkundige inrigtings, hospitale, dienste vir afgeleefdes en gestremdes, gevangenisse, ens. soveel moontlik oprig in die tuislande en selfs uit die blanke gebied daarheen verplaas.

Soos reeds aangetoon, het die blankes in die verlede byna alle aangeleenthede wat die Bantoe raak, uit 'n blanke hoek hanteer. Selfs in ons Bantoetuislande was dit hoofsaaklik die blanke administrateur wat daar as verteenwoordiger van die blanke regering opgetree het. Omdat dit noodsaaklik is dat die oë vir wat in Afrika gebeur, nooit gesluit mag word nie, en omdat selfs in ons buurgebiede onafhanklikheid reeds ' $n$ voldonge feit is, het dit gebiedend noodsaaklik geword dat ook die Bantoetuislande as selfbesturende gebiede gesien moet word.

Waar ons dusver dus ' $n$ blanke administrasie gehad het, waar die Bantoe hoofsaaklik as toeskouer opgetree het, sal hy in toenemende mate self sy eie sake bestuur. Ten einde dit te bereik, is daar nog baie sake wat reggestel moet word, veral in die vorm van administratiewe funksies en wetgewing, wat eintlik neerkom op volslae disintegrering van Bantoe-administrasie uit die algemene administrasiestelsel van ons land. Ter illustrasie noem ek net twee opvallende voorbeelde: die Bantoevolk het g'n eie maatskappyewette nie en moet ter stigting van maatskappye gebruik maak van ons wet, en vakleerlingskap kan deur Bantoe ook net verwerf word kragtens ons blankes se wet en stelsel.

Ten slotte is daar ook ' $n$ ander faset wat dusver nog nie in die openbare mening posgevat het nie, en dit is die noodsaaklikheid van ooreenkomste tussen die blanke- en Bantoeowerhede. Alle aangeleenthede wat van gemeenskaplike belang is, sal in toenemende mate by wyse van 'n tussenregeringsooreenkoms of -verdrag gereël en gereguleer moet word. Daar is so baie aangeleenthede van gemeenskaplike belang. Daar is 'n paar wat ek sal noem, omdat hulle van pertinente belang is. Daar is byvoorbeeld ekonomiese ooreenkomste waarby aangeleenthede soos die bemarking van produkte en artikels betrokke is. Ons weet dat groot getalle Bantoewerkers in die blanke gebied in diens is, en daar sal in toenemende mate in hierdie verband ook arbeidsooreenkomste aangegaan moet word. Tot dusver was die arbeidsverhoudings gebaseer op 'n heer- en diensbode-grondslag. In die toekoms sal dit al meer deur tussenowerheidsreëlinge bepaal word. 
Ons het reeds in verband met ons buurstate sodanige arbeidsreëlings aangegaan en alle dienskontrakte, tydperke van diens, dra van paspoorte, deurgange by paspoortbeheerposte en dergelyke meer, word in sodanige ooreenkomste voorsien. Ons sal ook so iets soos die leen van blanke tegnici en administrateurs aan Bantoe-owerhede, sowel binne as buite Suid-Afrika, in terme van sulke reëlings laat geskied.

Elkeen wat met toestande in Afrika in die algemeen en met Suider-Afrika in die besonder vertroud is, sal saamstem dat die voortbestaan en selfverwesenliking van volke alhier in ' $n$ groeiende mate van die verhoudings tussen die volke en tussen die betrokke regerings afhanklik word.

Die blanke gemeenskap alhier kan hom nooit losmaak van die feit dat hy in Afrika is en dat sy toekoms met die wel en wee van die buurvolke verbind is nie. Die blanke kan en moet dit verseker, ook ter wille van homself, dat die buurvolke nooit by die res van Afrika agterstaan vir sover dit die lewenstandaard betref nie.

Trouens, selfrespekterende volke respekteer ook ander volke, en die lewenspeil van die onderskeie volkslidmate bepaal die mate waartoe die wil tot bekamping en verwerping van vreemde ideologie spontaan na vore kom.

Ek wil afsluit met die gedagte dat ons blanke gemeenskap die geloof in ons toekoms kan versterk alleen deur die wete dat ons die harde werklikheid van ons taak moet begryp en dat ons die harde werklikheid van ons taak moet begryp en dat ons dus steeds fondamente moet lê waarop die geslag van môre met 'n oop gemoed sal kan voortbou.

Mag dit nooit vir ons nageslagte nodig wees om fondamente wat ons gele het, op te grawe omdat dit verkeerd en sleg gelê is nie.

M. C. Botha.

Kaapstad. 